\title{
ОНТОЛОГІЧНИЙ ПАСЬЯНС СУЧАСНОЇ ФРАНЦУЗЬКОЇ ФІЛОСОФІї
}

\section{С.В. Куцепал}

У сучасній французькій філософії одними 3 центральних можна вважати проблеми створення онтології багатоманітного, переосмислення класичної категорії суб'єкта та визначення відношення французької філософії до спадщини попередньої класичної традиції від Платона до М. Хайдеггера. Звернувшись до творчості Ж. Дельоза, провідною темою його обсервацій можна впевнено назвати тему Буття як единого, адже буття - це унікальна подія, де всі події сполучаються одна з одною; та тему однозначності Буття (l'univocité de l'Être), оскільки буття наділене єдиним змістом, $\epsilon$ порожнім простором події всіх подій, що виражається у нонсенсі смислом усіх смислів. При цьому варто зазначити, що Єдине має двоїсту природу ( $є$ і єдиним, i множинним), яка виявляеться в наявності бінарних пар на кшталт складка/зовнішне, подія/вічне повернення, сенс/парадокс тощо. Більш того, Ж. Дельоз уводить нову (власне, «стару» нову, адже це поняття йде ще з античності, а в XIX столітті дуже потужно звучить спочатку в німецькій класиці, а потім у російській релігійній філософії) назву ЄдиногоВсеєдине. У своїй праці «Розрізнення та повторення» він виголошуе лозунг: «Один единственный голос за тысячеголосое множество, один единственный Океан за все капли, единый глас Бытия за всех сущих» [3, c. 363].

У роботі «Логіка смислу» Ж. Дельоз перераховує основні атрибути Єдиного: «Одно событие для всех событий; один и тот же aliguid для того, что происходит, и для того, что высказывается; одно и то же Бытие для невозможного, возможного и реального» [2, с. 239]. А оскільки Єдине перетворюеться на Всеєдине, то у ньому завжди все 
вже наявне як у нескінченному та позалюдському першоджерелі, тобто ми пронизані актуалізацією Всеєдиного.

Беззаперечним авторитетом для Ж. Дельоза виступає філософія стоїцизму, оскільки стоїки розуміли Буття як всезагальність, та філософія $\Phi$. Ніцше, особливо його теза про неможливість визначити цінність життя. Ж. Дельоз задається питанням, чи може особистість вийти за свої межі, досягти ліміту своїх можливостей, прямувати туди, «куди відносить hybris». У такому розумінні думка перетворюеться на подію, існуе як розкол людської актуальності, як зникнення межі «ף». 3 огляду на існування лише Всеєдиного, виникає підстава для того, щоб умістити індивіда всередину його власних меж та надати сили для їхнього подолання, тобто рухатися до певної точки, «точки, где безличность умирания указывает уже не на момент, когда я исчезаю из себя, а скорее на момент, когда смерть теряет себя в себе, а также на фигуру, форму которой принимает моя единичная жизнь, чтобы подменить меня собой» [2, с.204]. Саме ця тотожність мислення та вмирання уявляється проявом істинного Буття.

$\mathrm{y}$ «Розрізненні та повторенні» Ж. Дельоз наділяе Буття голосомголосом думки. Це дає змогу стверджувати не лише можливість мислення про Буття, а й доводити, що саме мислення (думка) існуе лише завдяки тому, що Буття здійснюе дві одночасні операції-підкорюеться мисленню та озвучуе його. «Один голос создает гул бытия» $[3$, c. 54].

Як бачимо, наведена теза зовсім не заперечуе популярних, неодноразово розтиражованих висловлювань на кшталт «мова - дім буття», «усюди мова, текст, знаки», а лише підводить онтологічне підгрунтя під логічні структури когнітивних суджень. Філософ навіть уводить спеціальну категорію «онтологічне речення», де буття виконуе роль загального означуваного, виражається в одному й тому ж сенсі-в усіх означуючих або чисельно-відмінних виразниках. «В онтологическом предложении не только означаемое является онтологически одинаковым для качественно различающихся смыслов, но и смысл-онтологически одинаковый для способов индивидуации, численно различных означающих или выражающих» [3, с.54].

Таким чином, Ж..Дельоз утверджуе одну з найважливіших характеристик Буття - його однозначність, яка полягае не лише в тому, що Буття виражається одним єдиним змістом, а й у вираженні Буття в одному смислі в усіх відмінностях індивідуації, в усіх модальностях останньої. Неоднаковими є модальності, саме тому Буття виражається у відмінності. 
Дещо інакше подібна теза подаеться у «Логіці смислу». «Единоголосое Бытие содержится в языке, но происходит с вещами. Оно соизмеряет внутреннее отношение языка и внешнее отношение Бытия. Ни активное, ни пассивное, единоголосое Бытие нейтрально. Это - c6ерxБытиe, то есть минимум бытия, общий для реального, возможного и невозможного» $[2$, с. 216].

Наведені міркування $\mathcal{K}$. Дельоза можна розглядати також як аргументи проти одного 3 основних феноменологічних понять - «інтенціональність», позаяк тлумачення Буття як Єдиного вимагає відмови від твердження, що всі його іманентні актуалізації мають перебувати у відношенні взаємодії. У роботі «Фуко» Ж. Дельоз прямо говорить: «Знание неизбежно имеет две стороны: видение и говорение, язык и свет, что и объясняет, почему никакой интенциональности не существует» [7, с. 143], тобто слова та речі не маюоть жодних інтенціональних взаемовідносин.

Головною зброєю проти інтенціональності Ж. Дельоз оголошує диз'юнктивний синтез, котрий розподіляе серії, що розходяться, та поняття «складка». Розглянемо спочатку диз'юнктивний синтез. Диз'юнкція перетворюеться на синтез лише тоді, коли розходження та децентрування, які нею задаються, стають об'єктами утвердження, «расхождение утверждается так, что или ... или само становится чистым утверждением. Вместо исключения некоторых предикатов вещи ради тождества ее понятия, каждая вещь раскрывается навстречу бесконечным предикатам, через которые она проходит, утрачивая свой центр - то есть свою самотождественность в качестве понятия или Я. На смену исключению предикатов приходит коммуникация событий» $[2$, c. 210$]$. До речі, саме використання диз'юнктивного синтезу є тим, що відрізняе дельозівську критику інтенціональності від критики Хайдеггера, оскільки останній усе ж припускае існування інтенціональних взаємовідносин між актуалізованими вимірами Буття, спростовуючи лише «свідомість-сутність». Тому Ж. Дельозу значно ближча концешція М. Фуко, котрий утверджував байдужість сутностей до будь-яких відносин. Саме відмежувавшись від неусвідомлення М. Хайдеггером однозначності Буття, Ж. Дельоз подає свою визначальну тезу: «Всегда существовало только одно онтологическое предположение: Бытие однозначно» $[3$, c.53]. При цьому множинність значень Буття $е$ лише формальною, оскільки онтологічно вони є рівними та єдиними. За утвердження тези про однозначність Буття Ж. Дельозу доводиться заплатити досить високу ціну. Як стверджуе А. Бадью: «Мнжественное (сушности, значения) принадлежит в конечном итоге лишь к по- 
рядку симулякров, поскольку числовое различие, размещающее его во Вселенной, является, применительно к форме Бытия, к которой оно отсылает (мысль, протяженность, время и т. д.), чисто формальным, а применительно к его обособлению чисто модальным. Если, как и полагается, относить к симулякру любое различие, не обладающее ничем реальным, любую множественность, чей онтологический статус-статус Единого, то мир сущностей является театром симулякров Бытия» $[1$, с. 39$]$.

Ж. Дельоз вибудовує спеціальну логіку Єдиного, сутність якої полягає в обгрунтуванні необхідного існування двох імен, з яких на основі емпірії визначаеться одне, з якого й походить онтологічна однозначність Буття. Однією з таких пар (або «двійок Дельоза») виступає дихотомія «віртуальне/реальне». Домінуючим елементом пари, «іменем Буття» виявляється віртуальне, оскільки саме завдяки останньому певна актуальна сутність (симулякр) однозначно зберігае власне Буття. «Весь мир - не что иное, как виртуальность, существующая актуально лишь в сгибах выражающей его души, ибо душа действует благодаря внутреннему разгибу, посредством которого она составляет представления о включенном в нее мире» [4, с. 41]. Актуальне у потрактуванні Ж. Дельоза являє собою лише певне положення речей та досвіду, тобто план іманенції є тільки віртуальним. «Актуализация виртуального всегда происходит посредством различия, расхождения или дифференсиации. Актуальные термины никогда не походят на актуализируемую ими виртуальность» $[3$, с. 260]. Окрім того, віртуальне має такі характеристики: по-перше, воно виступае «нефілософським припущенням будь-якої філософської думки»; по-друге, виконує роль того, що прикріплюе сутність до її Буття; по-третє, Завдяки йому здійснюеться критика теорії референції, бо остання нездатна побудувати іманентність, перетворити віртуальне на реальне.

А.Бадью, полемізуючи з Ж. Дельозом, не визнає його концепції віртуального як Єдиного. «Виртуальное, даже в том случае, если оно последовательно мыслится как отличное от возможного, совершенно реальное, полностью определенное и строго как часть актуального объекта, не может приспосабливаться в качестве основания к однозначности Бытия-единого. По мере того, как Делез пытается вырвать его у нереальности, у неопределенности, у необъективности, само актуальное или сущность превращается в нереальное, неопределенное и, наконец, необъективное, поскольку оно раздваивается подобно призраку. Если мыслить в этом русле, вместо Единого устанавливается Двойное» $[1$, с. 75$]$. 
Одним із фундаментальних у філософї̈ є питання про взаємозв'язок мислення та буття. Дельоз тлумачить мислення як бросок костей, тобто воно постає диз'юнктивним синтезом та інтуїцією, а Буття мислиться як Єдине, тому традиційна методологія визначення відношень Буття та мислення для Дельоза неприйнятна. Французький філософ не може пристати на точку зору Декарта й пов'язати буття мислення 3 проблематикою суб'єкта, оскільки це суперечить тезі про однозначність Буття, наділяе Буття рефлективністю та негативністю; а ми вже з'ясували, що для Ж. Дельоза неприпустима навіть думка про те, що буття сутності може бути рефлексивним та негативним.

Пояснення цієї тези надзвичайно просте: сутність - це лише симулякр, перегинання поверхні, одна з модальностей Єдиного, тому вона за самою своєю природою не може мати ніякого відношення до інших об'єктів. За Дельозом, правом на існування наділена лише опозиція «зовнішне/внутрішне», у результаті якої відбувається «складання» зовнішнього (тому утворюеться «внутрішність»), тобто відбувається акт складання, народжується «складка Буття». Складка виконує дві основоположні функції: вона виступае одночасно й рухом поверхні, i лінією, яка розмежовуе зовнішність та внутрішність. Складка - це дія Єдиного, а «мислення співпадає з Буттям тоді, коли воно є певною складкою, чия жива сутність - складка Буття» $[6$, с. 125$]$.

Варто навести певні паралелі між доктриною складки у Ж. Дельоза та концепцією багатошаровості буття, яка була розроблена німецьким філософом Н. Гартманом. Таких шарів у Н. Гартмана чотири (фізично-матеріальний, органічно-живий, душевний, історично-духовний), усі вони переплетені між собою і певним чином субординовані. Більш вищий шар буття будується на більш низькому, але визначається ним лише частково. Взаємозв'язок шарів буття здійснюеться самим буттям, самою «гетерогенністю шарів буття».

У Ж. Дельоза коли зовнішне складається, то утворює внутрішне. Як результат топологічної операції складання породжується суб'єкт (складка зовнішнього). Цей суб'єкт позбавлений автономності, свободи та конструктивності й існує лише як думка. Саме суб'єкт позначає собою тотожність мислення та Буття, тому що «мислити-означає згинати, подвоювати зовнішне рівним йому за обсягом внутрішнім» [7, c. 154].

Зупинимося детально на розгляді поняття «складка», оскільки вона уявляється одиничним способом здійснення Єдиного. До речі, В. Подорога у післямові до російського перекладу праці Ж. Дельоза «Le Pli. Leibniz et le baroque» зазначає певну смислову бідність перекладу фра- 
нщузького «pli» російським словом «складка», стверджуючи, що «смысловая нагруженность понятия pli явно превышает возможности складки (русского эквивалента): первое отсылает не только к складке, но и к понятию сгиба, сгибания и разгибания (pli, repli, depli), а также к двойнику (удвоению, отражению, взаимоналожению)» [4, с. 246]. На думку російського філософа, «le pli» в основному визначається протидіючими силами, кожна з яких прагне підкорити іншу, сутність зазначених сил- згинання, згин. Тема онтологічної складки зустрічається не лише у Ж. Дельоза. Так, у М. Хайдеггера $\boldsymbol{\epsilon}$ потрактування суб'єкту як «просвічування» (просвет) Буття (Zwiefalt - двоскладчастість, складка, яка розрізняе та розрізняеться), яке постає засобом розриву 3 феноменологією, відмовою від поняття «інтенціональність».

У цьому зв'язку не можна не згадати одного 3 найвидатніших представників «онтології тілесності» М. Мерло-Понті, який також відмовляеться від інтенціональності шляхом доведення тези про те, що видиме та відчутне - це модуси одного буття, взаємодія яких здійснюється завдяки складанню. Між уявним і видимим французький філософ убачає тканину, що подвоюе їх, підтримуе, живить, але при цьому не $е$ річчю, а уявляеться «можливістю, латентністю і плоттю речей» $[5$, c. 124]. Замість інтенціональності М. Мерло-Понті уводить фігуру хіазму, яка має надфеноменологічну, топологічну природу. Саме завдяки хіазму легітимуеться місце плоті у глибинному вимірі Буття. «Наше тіло - це суще 3 двох листків, 3 одного боку, це річ серед речей, а 3 другого-той, хто їх бачить і торкається; ми кажемо, оскільки це очевидно, що воно поєднуе в собі ці дві властивості, а його подвійна належність до порядку „об'єкта“ і до порядку „,уб'єкта“ розкриває нам між цими двома порядками дуже несподівані стосунки» [5, с. 128]. Місцем постійного взаємопереходу внутрішнього (річ) та зовнішнього (тіло) постае плоть. «Побачений світ не існуе „у" моєму тілі, а мое тіло не існуе „у" видимому світі як в останній інстанції: як плоть, прикладена до плоті, вона не є оточеною світом і світ не $є$ оточений нею... Поверхова плівка видимого існуе тільки для мого бачення і для мого тіла. Але глибина під цією поверхнею містить моє тіло і містить, отже, моє бачення. Моє тіло, як видима річ, міститься у великому видовища. Але мое тіло, що бачить, лежить в основі цього видимого тіла і всіх видимих разом з ним. Відбувається взаємне входження і переплетіння одного $з$ одним» $[5$, с. 129$]$.

Плоть у М. Мерло-Понті наділяеться кількома атрибутами. Вона не $е$ матерією в сенсі часток буття, що додаються одна до одної чи продовжують себе для того, щоб утворювати сущих. Також плоть не $є$ 
духом і не є субстанцією. Це скоріше, одна зі «стихій Буття», зчеплена 3 місцем і $з$ тепер.

«Вона $е$ навиванням видимого на тіло споглядаючи і відчутного на тіло, що торкається себе в той час, як воно бачить і торкаеться речей, так що, водночас, як відчутне воно спускається до них, як таке, що торкається, воно пануе над ними всіма і виводить з самого себе це відношення і навіть це подвійне відношення через розкриття чи розщеплення своеї маси» [5, с. 136]. Місцем вивертання плоті е постае у М. Мерло-Понті складка.

Дещо відмінне потрактування складки надається Ж.Дельозом, який стверджуе, що складки бувають двох типів - складки матерії та згинання у душі. Ілюстрація співіснування зазначених типів склалок надається французьким мислителем у топологічному вимірі, за допомогою образу лабіринту, коли рівні останнього прирівнюються до топосу складки, - лабіринт безкінечності у матерії та її окремих частинах і лабіринт свободи у душі та її предикатах. На думку ЖЖ. Дельоза, помилкою Декарта і його послідовників було прямолінійне тлумачення протяжності та мислення, ігнорування можливостей викривлення, еластичності тіл та «вібрацій та коливань матерії. Відштовхуючись від барокових принципів мислення, Ж. Дельоз стверджує, що складка завжди знаходиться всередині складки як порожнина у порожнині, що вона не точка, а лише окантовка лінії, найменший елемент лабіринту. Кінцевою метою згинання є утворення включеності та приналежності. Те, що згинається, е лише віртуальним, котре отримуе свою актуальність лише в оболонці, всередині тієї речі, що огортає його. Оболонкою згинання Ж. Дельоз вважає душу, суб'єкт (= монада Лейбниця). Єдине таким чином наділене властивістю згортатися та розгортатися на відміну від множинного, що є невіддільним від згинань у той час, коли воно зігнуте, та розгинань, коли воно розгорнуте.

Ж. Дельоз також виділяє так звану «ідеальну складку»-інфлексію (вгинання), яка створюе умови для можливого згинання або складання, котра $\varepsilon$ рівнодіючою і в матерї̈, і в організмах, і в душах. Інфлексії постійно й у всіх напрямках виникають та зникають, являють собою множину невеликих складок. Більш того, як стверджуе Ж. Дельоз, «сингулярное - это инфлексия, точка инфлексии, продолжающейся до смежной с другими сингулярностями области, благодаря чему сообразно отношениям дистанции образуются мировые линии; затем - это центр искривленности вогнутой стороны в той мере, в какой он определяет точку зрения монады согласно отношениям перспективы; наконец, это заметное, сообразно дифференциальным отношени- 
ям, формирующим в монаде перцепцию» [4, с. 156].

Від світу до суб'єкта перехід здійснюється завдяки викривленню, яке надає змогу світові актуально існувати у суб'єктах, але водночас, усі суб'єкти співвідносяться з цим світом як власною віртуальністю, що отримала змогу актуалізуватися. Іншими словами, світ має характеристику замкненості, і саме остання надае йому змогу знову починатися у кожному суб'єкті (у кожній монаді, якщо користуватися термінологією Лейбніца). Для того, щоб суб'єкт існував для світу, спочатку слід укласти світ у суб'єкт, тобто створити складку між світом та душею.

Наслідуючи стоїків, які піднесли подію у ранг поняття, розглядали подію як безтілесний предикат суб'єкта речення, та лейбніцівське потрактування світу як події, що є віртуальним (безтілесним) предикатом, уключеним до складу суб'єкта, Ж. Дельоз утворює власну логіку події.

Для нього суб'єкт безпосередньо пов'язаний із подією, оскільки те, що включається у поняття у вигляді суб'єкта, завжди або маркована дієсловом подія, або марковане дієсловом відношення. У цьому випадку Ж. Дельоз знову послуговується ідеями Г. Лейбніца , котрий визначав суб'єкт через його власну єдність, а предикат потрактовував як дієслово, що виражає дію, тоб̆то $є$ перш за все відношенням, подією, а не атрибутом (Дельоз вважае це проявом так званої «барокової граматики»). Предикат - це власне речення, тому висловлювання «я мислю» неможливо звести до висловлювання «я $є$ мислячим», бо мислення - це не постійний атрибут, а предикат як безперервний перехід від одніеї думки до іншої.

У цьому контексті варто пригадати кантівський приклад з аналізом 100 талерів реальних та 100 талерів можливих. За І. Кантом, і в реальних, і в можливих 100 талерах сума однакова, тобто реальність не містить у собі нічого більшого, ніж просту можливість. Але коли 100 талерів потрапляють до кишені, то відбувається перехід від поняття (як можливого) до існування (дійсне), але капітал власника кишені вже зовсім інший, він змінився. На основі цього І. Кант робить висновок, що буття не тотожне пізнаному буттю, тобто існування не $\epsilon$ предикатом речі, воно переходить у вимір незбагненого, вислизае від поняття, проявляеться у вигляді можливості, випадку, необгрунтованого тощо. Наведені вище розмисли Ж. Дельоза постають також і інтенцією кантівської думки.

Складка у Ж. Дельоза має топологічну природу, завдяки чому утверджується базисна цілісність Буття, яка позбавляє сенсу існування пари «зовнішнє/внутрішнє» у дійсності. Лише на місці складки, у то- 
чці топологічного вивертання виникае негативність між членами зазначеної опозиції. Варто також відзначити ще одне значення складки: завдяки наявності складок утворюється топологія світу, виникає можливість картографування топосу, а звідси вже лише один крок до ризоматичності, оспіваної Ж. Дельозом у дуеті з Ф. Гваттарі.

Буття уявляється Ж. Дельозом як палітра розходжень та невідповідностей, оскільки жодна сутність не володіє правом зовнішнього положення стосовно всіх інших, вона позбавлена того, що можна назвати «зовнішністю» (extériorité), але, одночасно, у неї немає й внутрішнього утворення (intériorité). Звідси - відсутність здатності до співвідношення 3 самою собою (рефлективність) та до співвідношення 3 іншими сутностями (негативність). Зовнішнім зовнішнього та внутрішнім внутрішнього стає складка Буття, тобто думка, оскільки опозиція внутрішнього та зовнішнього проявляється саме при складанні. Наслідком цього стае те, що внутрішне розуміється як утворене зовнішнім, тому дієслово «мислити» співпадає з дієсловом «бути». Буття перегинається, результатом такого перегину стає утворення суб'єкта, через якого буття має змогу мислити себе. При цьому Буття мислить себе як зовнішне, те, що неможливо помислити, знаходиться всередині думки. Думка трансформується на «думку Зовнішнього».

Проти дельозівської концепції складки виступае французький філософ А.Бадью, який загалом надзвичайно високо оцінював філософську постать Ж. Дельоза. Він називає його філософом, що надає рішучу критику репрезентації, пошук істини замінюе логікою сенсу, замість трансцендентних ідеальностей утверджуе в правах творчу іманентність життя, осідлий номос Сутностей замінюе на кочовий номос тимчасових актуалізацій, серій, що розходяться. Саме Ж. Дельоза він проголошуе «винахідником сучасного Бароко», «захопленим мислителем плутанини світів». Проте ідея складки викликає його заперечення.

Апелюючи до того, що одне з імен Єдиного- Пам'ять, А. Бадью стверджує, що складка - це ніщо інше як подвоєння Пам'яті, тобто відновлення минулого. «Складка превращает любую мысль в имманентную особенность того, что уже есть, и отсюда следует, что любое новшество является отбором из прошлого путем сгиба» [1, с. 123]. Ще одним ім'ям Єдиного є віртуальність, відповідно складка - це подвоєння. актуалізація Віртуального. Тому втрачає сенс теза про наявність справжнього нововведення, бо усе, що виникає, - це лише повторення вже існуючого.

Таким чином, можна стверджувати, що друга половина ХХ століття позначена збільшенням інтересу до натурфілософії, онтології. У 
цьому контексті неможливо оминути увагою досягнень М. Хайдеггера 3 його фундаментальною онтологією, де головною установкою залишається спрямованість на предмет, тобто інтенціональність. Відбувається своєрідна дискусія між фундаментальною німещькою традицією філософування, що вкорінюеться на глибині та інтенціональності, та французькою, прозорою та поверховою. Прикладом останньої постає онтологія Ж. Дельоза, для створення якої використовуються більш вишукані «матеріали», здійснюеться відмова від глибини, використовуються нові карти при побудові онтологічного пасьянсу - замість «тутбуття» М. Хайдеггера з'являється «поверх-буття» Ж. Дельоза.

\section{1 Бібліографія}

[1] Бадюю А. Делез. Шум бытия: Пер. с франц.-М.: Логос-Альтера, 2004.

[2] Делёз Ж. Логика смысла: Пер. с франц.-М.: Академия, 1995.

[3] Делёз Ж. Различие и повторение: Пер. с франц. - СПб.: Петрополис, 1998.

[4] Делёз Ж. Складка. Лейбниц и барокко: Пер. с франц. - М.: Логос, 1998.

[5] Мерло-Понті М. Видиме й невидиме: 3 робочими нотатками: Пер. 3 франц. - К.: КМ Академія, 2003.

[6] Badiou A. Gilles Deleuze «La clameur de l'être»-P., 1997.

[7] Deleuze G. Foucault.-P.: Minuit, 1986. 